\title{
THE STYLISTIC ORIENTATION OF PRIMOŽ RAMOVŠ
}

\author{
Andrej Ri javec (Ljubljana)
}

The title of the present article appears to be reasonably clear. Still, from the very beginning one could take completely relative courses if one questioned conceptions such as "style", "orientation" or "stylistic orientation", conceptions which have been over and over again but neither completely nor satisfactorily defined. As many authors, so many variants, be it one consults Yugoslav lexical literature where in the Musical Encyclopaedia (Muzička enciklopedija) under the entry "style" one reads that "style in music is the totality of creative traits which distinguishes the activity of one composer from the activity of others" 1 be it that one consults such a standard reference work as Die Musik in Geschichte und Gegenwart; here under "Definition" one finds: "Der Stil einer Komposition ist eine unterscheidende Eigenschaft, die die Eigenart der Kräfte, welche eine Musik gestaltet haben, darstellt"; a little further it is conceded that style can be considered also in a "purely objective sense", i. e. it can be defined through concrete structural characteristics. ${ }^{2}$ Or, for example, Enciclopedia della musica, Ricordi: "Stile - L'insieme dei caratteri che concorrono a definire l'individualità di un artista creatore, di un'opera, di un periodo". ${ }^{3}$ In his Harvard Dictionary of Music Willi Apel disposes of the problem with the help of Webster's dictionary - "Distinctive or characteristic mode of presentation, construction or execution in any art", " whereas Grove's Dictionary of Music and Musicians apparently evades this tricky question. And so on and so forth. The theoretical points of departure for this subject thus appear to be unsolved and this could logically lead to the conclusion that it is really futile to pursue this task, for if the initial criteria are not clear and solid what can be then said about the superstructure! Still, in spite of inadequate "tools" let us set to work so that we

1 Vol. 2, Zagreb 1963, 644.

2 Bd. 12, 1965, 1302.

3 Vol. 4, Milano 1964, 290

${ }^{4}$ Cambridge, Mass. 1958, 714. 
keep in mind the fogginess of stylistic epitheta, which means that stylistic labelling will be used only as an auxiliary means of presentation. Finally, to open problems is more important than to close off solutions, for due to the characteristic stylistic development of Ramovš's personality the present article might at the end, despite its theoretical deficiencies, turn out to be a contribution even to this, seemingly weaker, point of the theme in question. Modern scientifically oriented psychology of behavior has already proved that verbal articulation of impressions and of what has been intelectually attained has not only a descriptive but also a cultivating quality; which means: the richer our vocabulary the more differentiated our sonorous experiences and musical thinking. ${ }^{5}$

Whereas the first half of the theme as formulated might be questionable any doubt about the choice of the composer Primož Ramovš seems to be superfluous. He is known to be the leading living Slovene composer, and belongs to one of those forming the summit of modern and even avantgarde Yugoslav musical trends. Hardly is there a festival of contemporary Yugoslav music where his compositions would not be prominent. The ever-increasing quantity of his compositions has been accompanied by successes abroad, and his name represents an efficacious and at the same time a worthy "export product" in the repertoire of many a Yugoslav soloist and ensemble. At the same time it should be emphasized that he is a composer who has become and remained modern without "serving abroad", a composer (and this is the key to his selection) who represents a most continuous personification of all those efforts and ideas advocated between the two wars by composers such as Slavko Osterc, Josip Slavenski, Miloje Milojević and a few others. Because of his importance and repeatedly proven musical qualities Ramovš is interesting both as a Slovene as well as a Yugoslav composer. And it is precisely Ramovšs inner development, the development of his stylistic searchings which is all too little known. The analysis of the latter is worth the effort for it will give an answer to the theme formulated in the title: it will draw attention to the phases of Ramovš's development and to the pluralism of his stylistic orientation, of which the most recent stage cannot be adequately defined even through a most loose application of traditional stylistic labels. ${ }^{6}$ Which demands a revaluation of stylistic conceptions and causes doubt about encyclopaedic entries, especially when treating later and the latest music written in this century, which again does not negate the reasonableness of this article.

Primož Ramovš was a pupil of Slavko Osterc; perhapse his most successful, at least in the field of composition. Just before the end of Ramovš's Ljubljana studies the occupation came - in spring 1941,

${ }^{5} \mathrm{zfmth}$ (Zeitschrift für Musiktheorie), Jg. 3, 1972/2, 18.

${ }^{6}$ Cvetko D., Zum Problem der Wertung der neuen Musik, International Review of the Aesthetics and Sociology of Music, Vol. IV., No. 1, 1973, 10. 
only to be followed soon by the death of Osterc. Had it not been that way, the twenty-year-old Ramovš would have probably gone to Prague as many before him... Coincidences, the niceties of which belong into the composer's biography, led the young Ramovs to the summer course "per gli stranieri" in Siena, to Vito Frazzi, an admirer of Richard Strauss. The first contact with a foreign country was rather disappointing, both as regards the general musical level and the "belcantistic" stylistic orientation. His "stile patologico", as they labelled it, found no place here. Next, he spent two years of private studies with the neoclassically thinking Alfredo Casella in Rome; here, with his innate dispositions, he worked on the early scores of Stravinski, Prokofiev and Hindemith. All this, as well as the previous strict Osterc's school which always encouraged creative independence, made a successful start possible. This point is characteristically reflected in the Third Divertimento for string orchestra (1943), from its neoclassical clarity of form to the sublimated dancing lightness of the quick movements, from the tonality of language to the typically (neo)baroque falling ostinatos, from the captivating, sometimes slightly lyrical but always jovial flow of sound to the characteristic motoric motion. The most extensive composition of Ramovš's neoclassical phase is his Third Symphony (1948). In the search for additional, generalizing stylistic coordinates one could in connection with the march episode of the Presto speak of analogies with the more "daring" Prokofiev or "naturalistic" Shostakovich. A kind of bucolic lyricism is still present. However, dramatic intensifications and erruptions of sound, so typical of the composer's newest works, cause more and more surprise. The concluding movement contains an exquisite stylistic treat which, considering Ramovšs present orientation, is all the more surprising: the victorious, dorian conclusion with salient wind, brass and timpani is a striking example of the hymnal socialist realism.

After this digression two, nowadays already classical, scores come to the fore: the Sinfonietta (1951) and Musiques funèbres (1955). The former is stylistically purer than for example the Third Symphony and certainly more dissonant than the previously mentioned Divertimento which represents a more tender, suite-like variant of Ramovš's neoclassicism. It must have been under the influence of his Italian studies that in spite of everything he did slightly deviate from Osterc. Here, in the Sinfonietta, this temporal traditionalism begins to crumble. Many a well-known trait has remained: in form, in echoes of indefinable folkloricity, which reminds of hindemithian neoclassical playfulness (Vivace), in the neobaroque motoric flow, and last but not least, in passages near to neat dance episodes in Prokofiev's "Romeo and Juliet" (not to mention the typical harmonic progresssions) as reflected for example in the second trio of the already mentioned third, Vivace movement: ${ }^{7}$ 


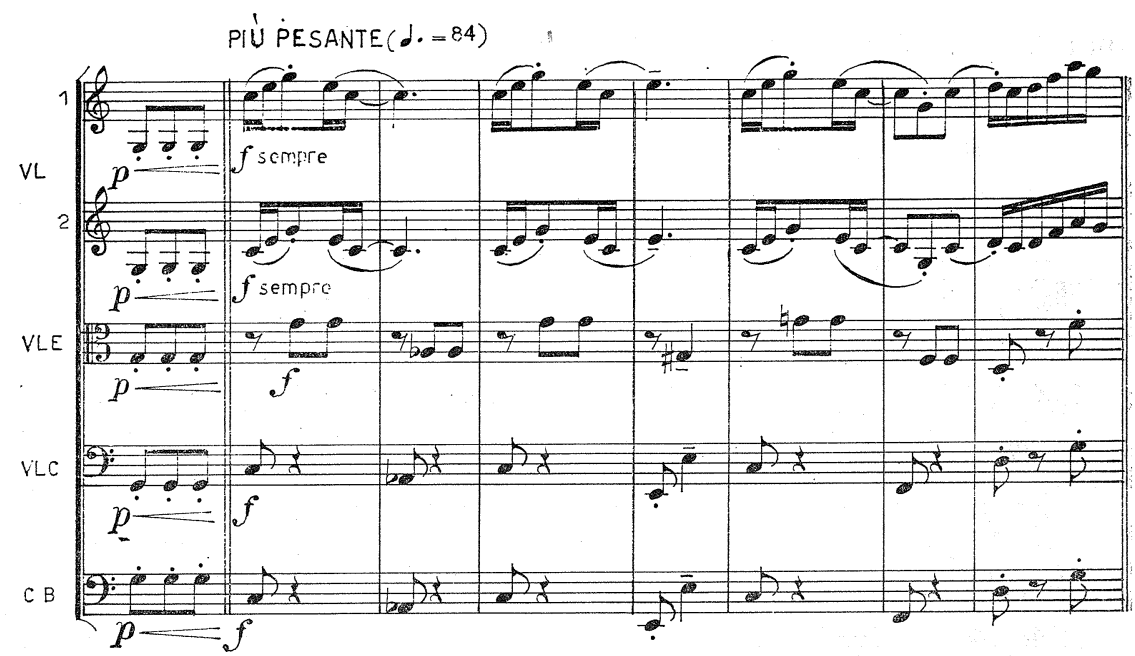

There is more linearity in the movement of the voice-parts; tonality no longer rests on chords by thirds but, taking into account other intervals, especially seconds and fourths, revolves around a chosen tonal centre. The already exploited traditional language forces Ramovš to quit the tertian system. In harmony, this is reflected in chords by fourths. Still, in the Sinfonietta they are not "real", for one actually has to do with doubled "barren" fourths and fifths

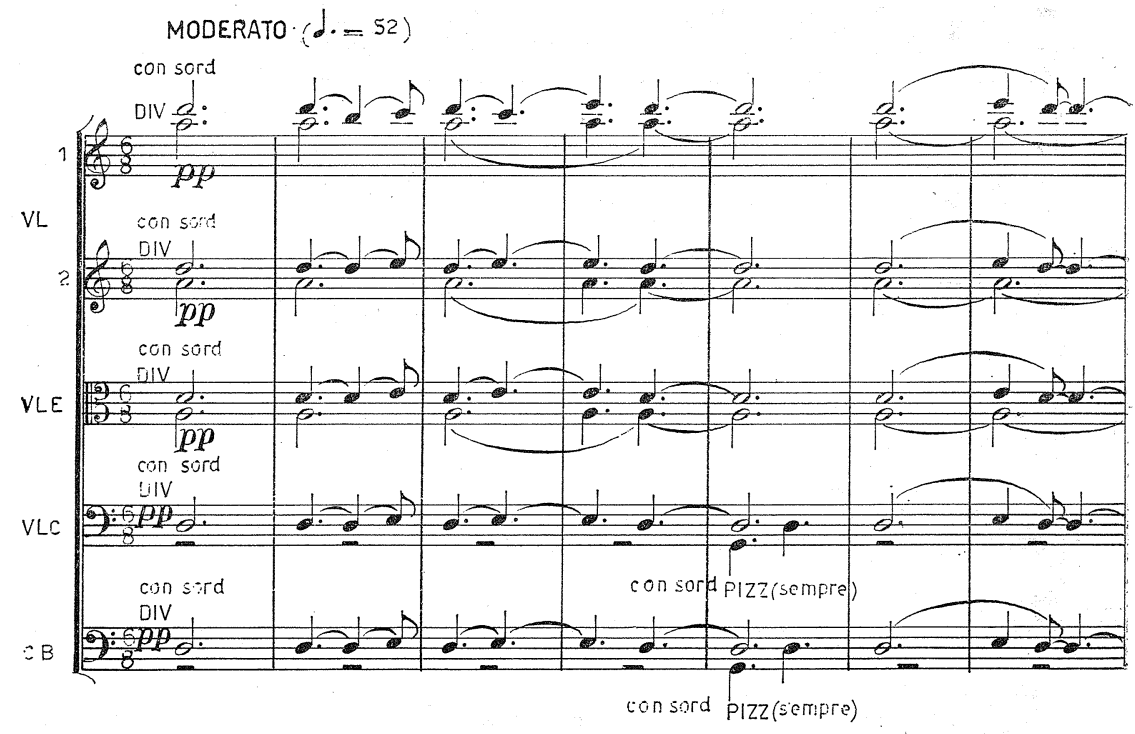

7 Sinfonietta, score, DSS (Društvo slovenskih skladateljev) 708, Ljubljana 1965, 59. 
that bestow for example a static, pastoral, although non-programmatic, character on the second movement. ${ }^{8}$

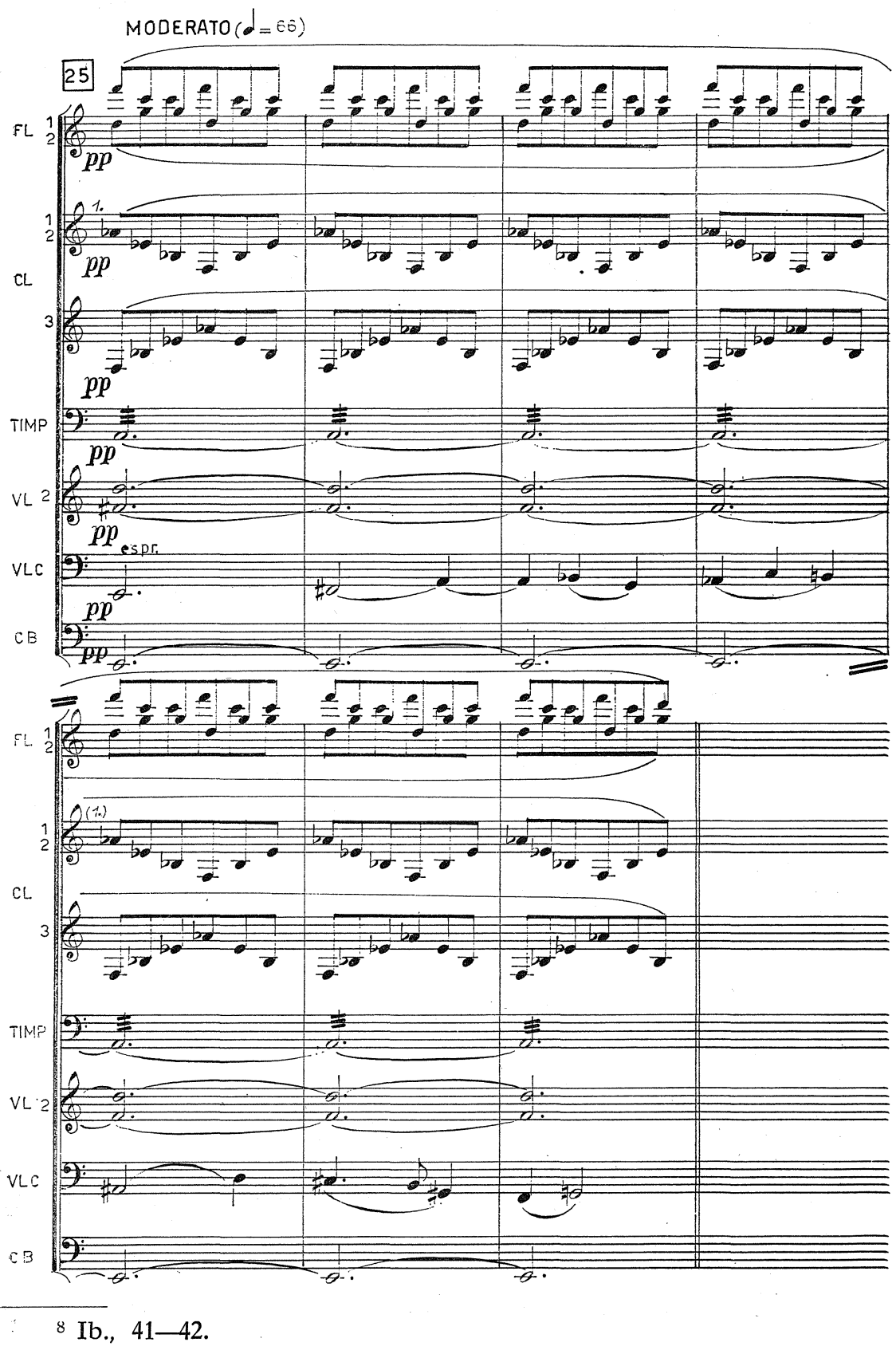


Though aesthetically successful, in Musiques funèbres Ramovš's compositional crisis is even more pending. Neobaroque is only the fifth movement, in the form of a ciaccona, which means that the composer is more or less abandoning traditional forms. The motoric, perpetuum-mobile-like pulsation is still present, but it operates always with the same, only quantitatively, changing intervals (especially seconds), mostly in a field of equal, functionally detached half-tones. "Barren" intervals are there too as well as chords by fourths, both in the role of islands of peace within more dissonant harmonies, immanent supporters of Ramovš's dramatic vein. Only a little, and even these will be forsaken - being all too neutral and inexpressive. ${ }^{9}$

Searching and groping for the unknown, in the following years Ramovš does not write symphonic works. Abstract pondering and theoretical advocacy, the latter very often only a camouflage of one's creative impotence, is not to his liking, So, he writes chamber compositions. These kinds of analogies, from the past and the present, are at hand and significantly characterize Ramovš, as a practical musician. During these searchings a stylistic branch springs up which in the last instance, in spite of its own "hopelessness", temporally coincides with a composition 'that helps Ramovš to further productive years. At the beginning of this backwater stands the Sonatina for French horn and piano (1959), which represents the final farewell to traditional tonality. Here, an enlarged and complicated sonata form copes with atonality, whereas obsolete dodecaphonic principles are present in the Variations for piano (1960) and Con-

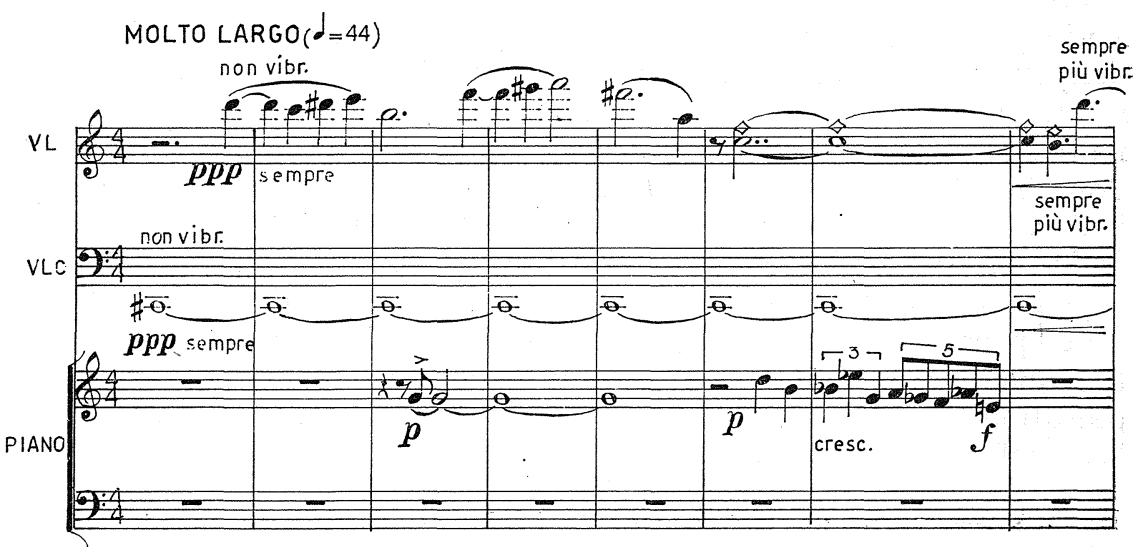

trasts for piano trio (1961)..$^{10}$ Only a step and Ramovš too will enter

${ }^{9}$ Musiques funèbres, score, DSS 462, HG (Hans Gerig) 683, 42-43. 1966, 2.

${ }^{10}$ Contrasts for violin, violoncello and piano, DSS 279, Ljubljana 
the waters of exceedingly intelectualized composing. ${ }^{11}$ Pentektasis for piano (1961) is his first and last totally organized composition. He himself had to convince himself about the sense and non-sense of this system, of its possibilities and its limitations. The fact that four years earlier Pierre Boulez had inscribed his name in music history with his famous lecture "Alea" was for Ramovš irrelevant. More interesting is the fact that Ramovš gave up all efforts in this direction at a time when extolling of schematic serial principles was definitely over also in Darmstadt. ${ }^{12}$

It was during this period that external coincidences helped Ramovš to overcome this cul de sac, without making a pilgrimage to Darmstadt or some other avantgarde centre in West Germany, of which neither the theorizing aptitudes nor the compositional results were much to his liking or close to his aesthetic ideas. The "salvation" was to come from elsewhere; it came with the helpful shock Ramovš experienced in contact with new Polish music and the propitious zephyr that began to blow in Yugoslav music with the birth of the Zagreb Biennale and other similar festivals. A visit to the Warsaw Autumn in 1960 only gave the last impetus to forces already latent in his musical striving.

In Ramovš's idiom one can thus follow a development commencing with an evergreater evasion of tonality, continuing through a shorter, natural episode of atonality, dodecaphony and total organization only to ascend the world of new sound. On the transition between the two worlds, yet within the main current of his development, stands the Concerto for violin, viola and orchestra (1961), the first visible result of his visit to Warsaw "although the technical traits characteristic of his recent works are not yet discernible". ${ }^{13}$ The stylistic crisis spoken of in Musique funèbres is even more evident in this Concerto, as it is bounding with the past, and symptomatic of the future as well as reflecting Ramovs's simultaneous atonally-dodecaphonic activity. ${ }^{14}$. It is already in the above mentioned Sonatina that the lyrical note had vanished and that the composition had changed into an atonal (though not athematic), arabesque-like and perhapse slighty dull motoric flow of sound. A similar motoric flow is also in the Concerto; it is still continuous, still an imperative that "prosecutes". Nevertheless, one passage in the score forecasts the qualitative change which is to affect this neobaroque motoric pulsation: it will become "disoriented" and, turning into a swarming layer of sound, enrich Ramovš's means of expression. ${ }^{15}$ Additional

11 Karkoschka E., Uber Exaktheit in Musikanalyse, zfmth, Jg. 4, 1973/2, 3.

${ }_{12}$ Dibelius U., Moderne Musik 1945-1965, München 1966, 222-225.

13 Petrić I., P̈rimož Ramovš, Koncertni list Slovenske filharmonije $1969 / 70,7,5$.

${ }_{14}$ Cf.' the incipit of the viola on page 3 of the Concerto for violin, viola and orchestra, DSS 187, Ljubljana 1964.

15 Ib., 52. 

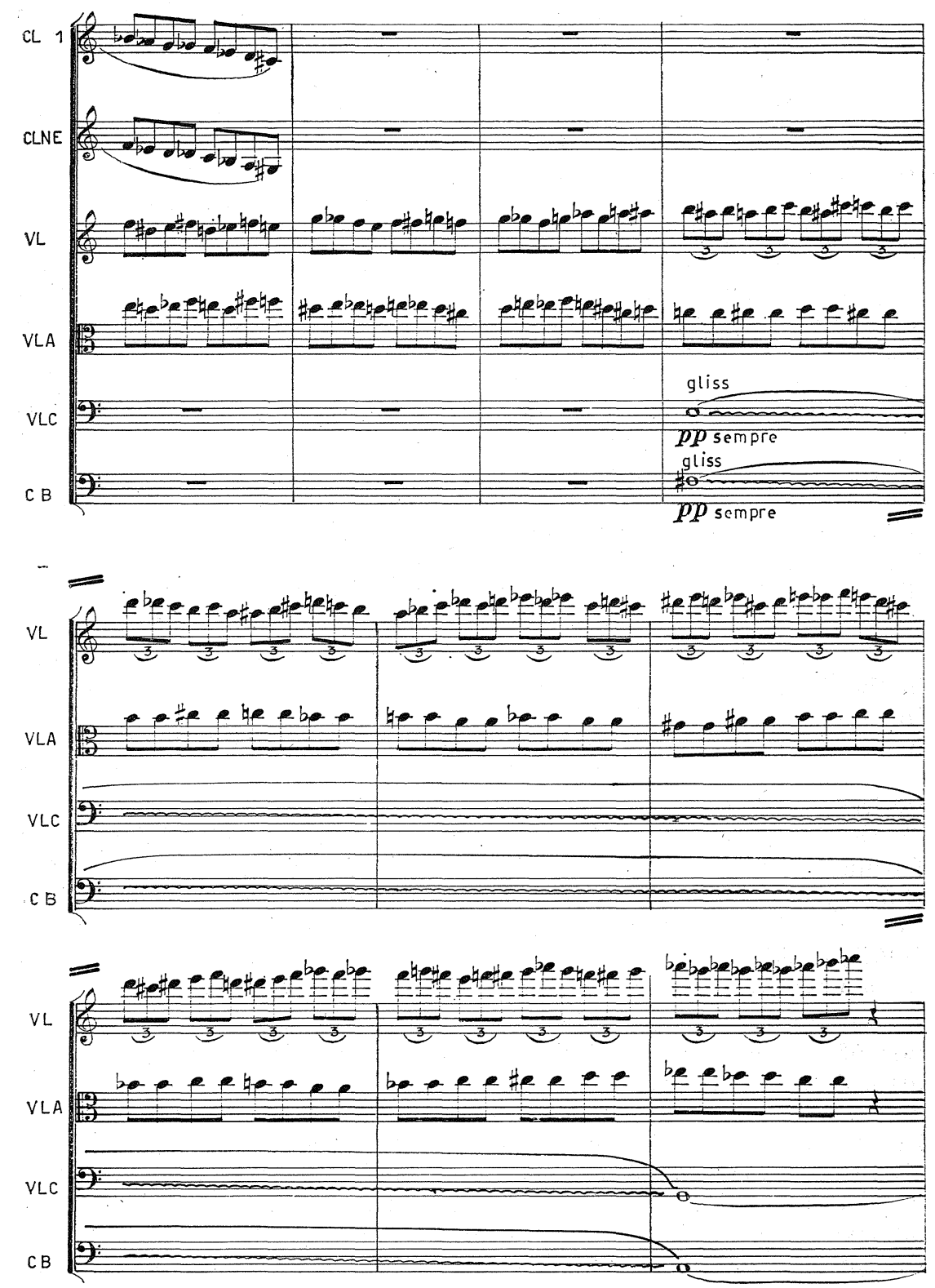

triplets going into the high register and the descending glissando in seconds, in the low strings, are pushing the hitherto even rhythmic pulsation on the verge of tone colour. Other elements of the texture are experiencing a similar fate: atonal tatteredness of soloists' lines is 
increasing their expressive, or even (neo)expressionist quality, ${ }^{16}$ whereas compound harmonies by fourths and especially by seconds are intensifying dramatic points in the work.

The first really new composition, a composition that was written nearly simultaneously with Pentektasis for piano, is Enneaphonia for chamber ensemble (1963) commissioned for the Warsaw Autumn 1963. "Due to the purpose and place of performance Ramovš gave up the traditional metric notation and the square structure of individual passages. For the first time he introduced aleatorics and sought for unusual colour effects and contrasts to replace former structural elements. One should admit that he succeded in the greatest possible extent and that even today this composition, after he has acquainted himself thoroughly with these kinds of expressive possibilities, remains a work not outrivalled even by his later masterpieces". ${ }^{17}$ The notational picture had to change greatly; however, not to the extent that parallel passages in the Enneaphonia could be, for example, considered a complete novum without any connections whatsoever with the culmination of the development of the stylistically completely different and two decades older, neoclassical Sinfonietta. ${ }^{18}$ In both cases one has actually to do only with two variant solutions of pure bartókian Klangmusik. ${ }^{19}$ (Cf.pp. 89-90.)

What hapenned in Enneaphonia in chamber music occured later in the field of orchestral composition. But not immediately. Profiles for orchestra from 1964 contain the last echo of motoric pulsation in the old sense as well as of a score written out in full, which was more and more of a burden for the performers. Step by step Ramovš explores and masters the sound material freed from any fetters. From the chamber world he grows into the symphonic one: the Parallels (1964) are only for the piano and strings, apart from the flute and strings the Echoes (1965) introduce four clarinets, four French horns and four percussionists, whereas in the Antiparallels (1967), besides the piano, he makes use of the whole orchestra only to achieve symphonic dimensions in Symphony 68 (1968).

Along with these works and later on, Ramovs composes a number of chamber works. "We are confronted with a composer who masters the sound with ease, a composer who is enthusiastic about any combination of sound. In spite of the great diversity of titles Ramovš appears to be our most abstract composer, a musician who creates from the sound and for the sounds's sake. Which is the purest way of composing, and the least speculative at that: to achieve, without extra-musical influences, the maximum intensity of sound and of the latter's iridescence in place and time. With Ramovš one has the

\footnotetext{
16 Stuckenschmidt H.H., Was ist musikalischer Expressionismus?, Melos, januar 1969, 1.

17 Petrić I., ib., 6. $26-27$

18 Enneaphonia, score, DSS 250, Ljubljana 1967, 39; Sinfonietta, ib., 19 Traimer R., Béla Bartóks Komponistionstechnik, Regensburg 1967, 32.
} 


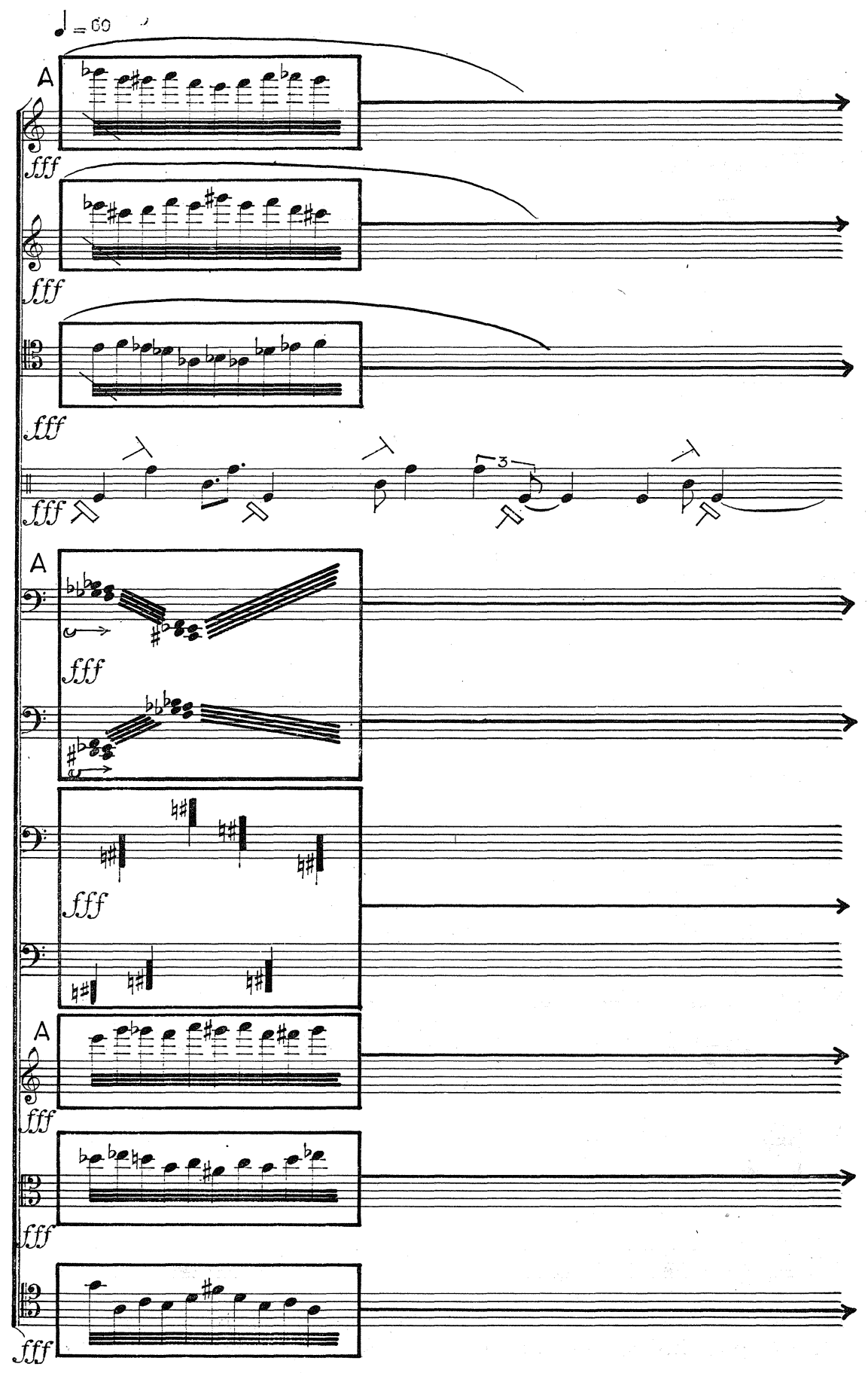




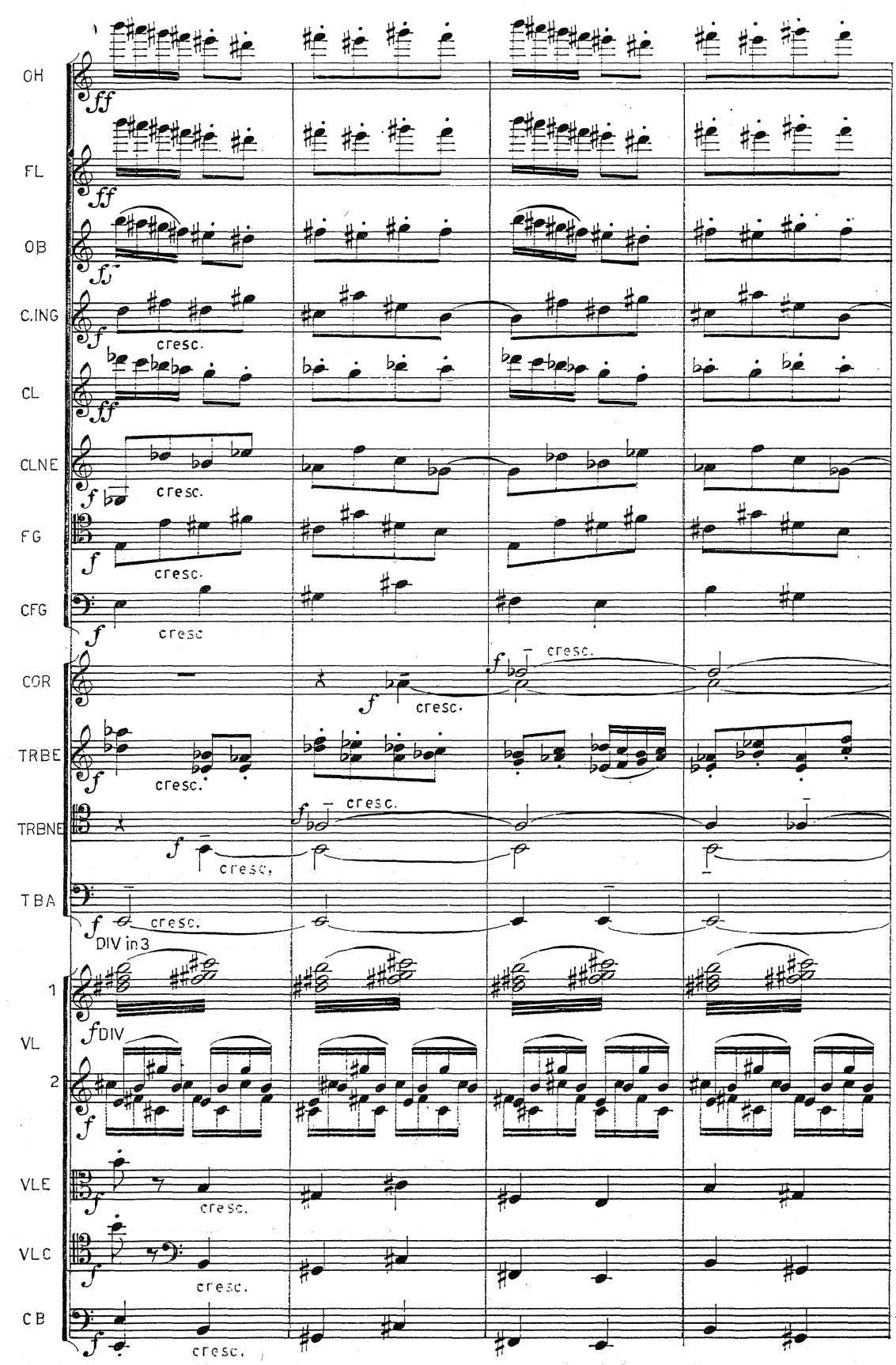

feeling that nearly with every composition he has employed the utmost possibilities of sound combinations: he is neither ashamed 
of the greatest gradations or instrumental cries nor of the most concealed whispers or long resting timbers". ${ }^{20}$

In the above quotation it has been said that Ramovš's compositions have diverse titles. That is true. However, it should be noted that, similarly to inspiration "he discovers mostly in the abstract and imaginary world of music", 21 the titles as well reflect sound relations or sound pecularities of certain compositions. It is so with the Profiles, the Parallels, the Antiparallels, the unmentioned Oscillations for flute and chamber ensemble (1967), as well as with compositions which followed Symphony 68: in the Contrasts for flute and orchestra (1969) the structure is based on the contrast "one against all", in the Symphony between the piano and orchestra (1970) Ramovš is solving the question of timbre as regards the piano being also a percussion instrument, which leads him to enlarge the percussion group with the marimba, xylorimba and vibraphone, or, in the Syntheses for French horn and three orchestral groups (1971), with the help of metal percussion instruments, the metal sound of the horn is extended and connected with other orchestral groups. And so on and so forth. Regarding "title" connections the Echoes

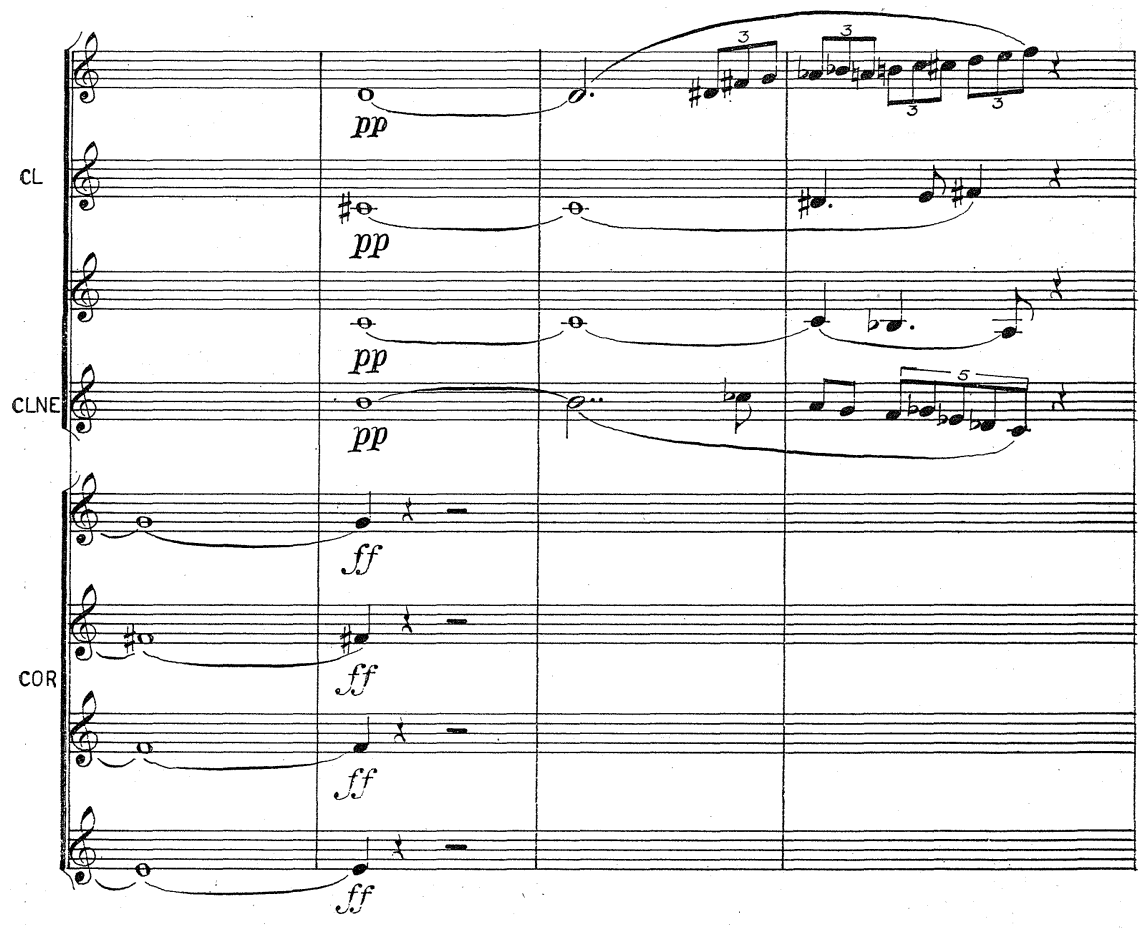

20 Petrić I., ib., 7.

${ }^{21}$ Reich T., Susreti sa suvremenim kompozitorima Jugoslavije, Zagreb 1972, 284. 
come especially to the fore; one only has to note the harmony of horns in fortissimo, broken off and continued in another tone colour in the clarinets (cf.p. 91),

or, how different ways of performance on the flute find their echo on a recorder at the back of the concert-hall,

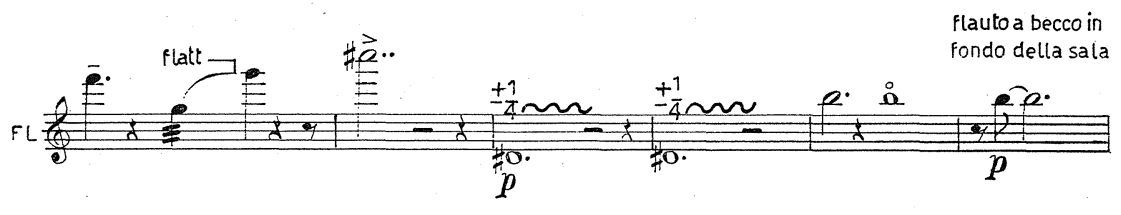

or how the dinamically louder half of the divided strings evaporates, con sord

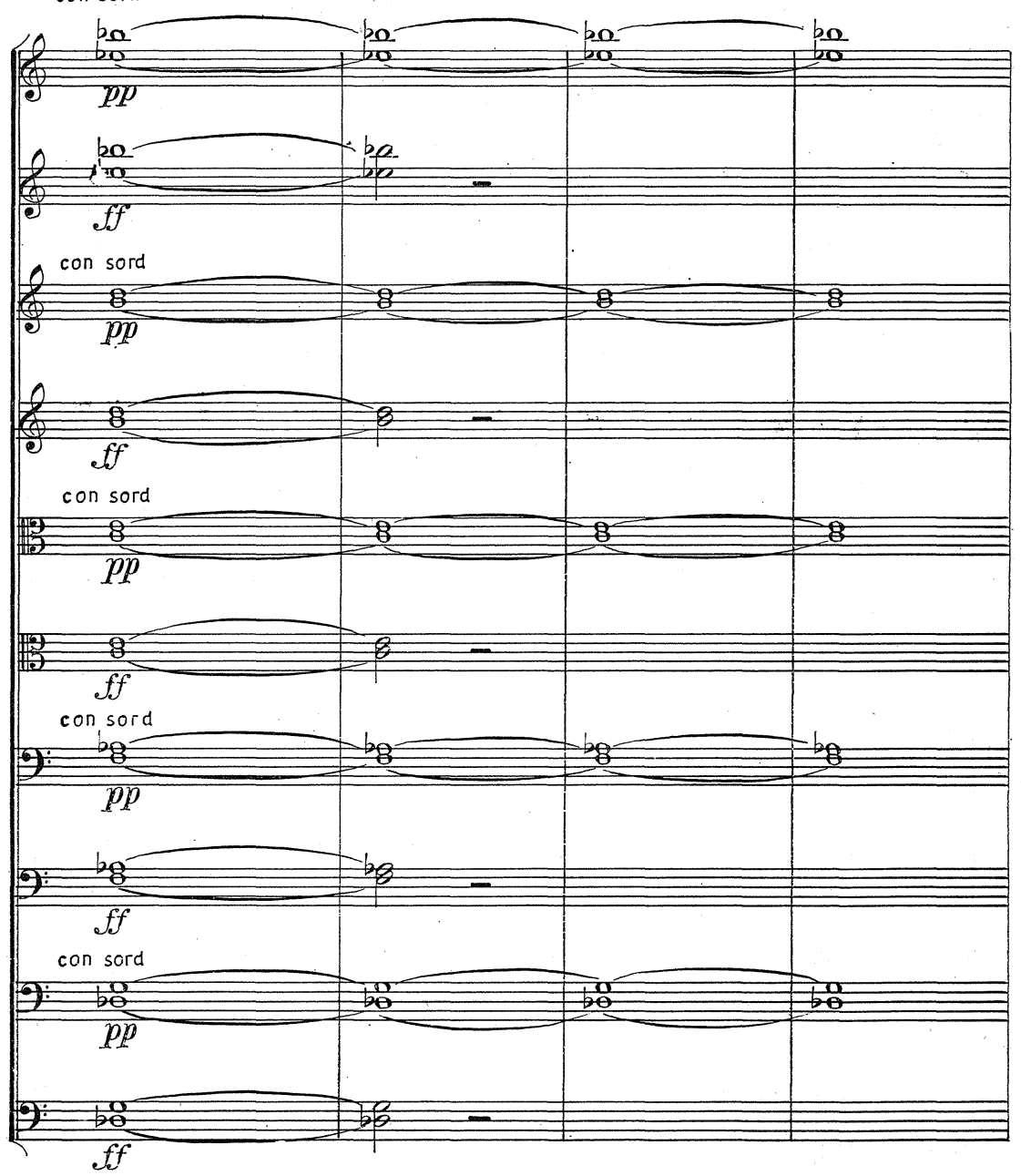


or how this reechoing exchange becomes the essential formative element of the second movement which is exclusively based on the noise of the strings. ${ }^{22}$ This is of course, mutatis mutandis, only a

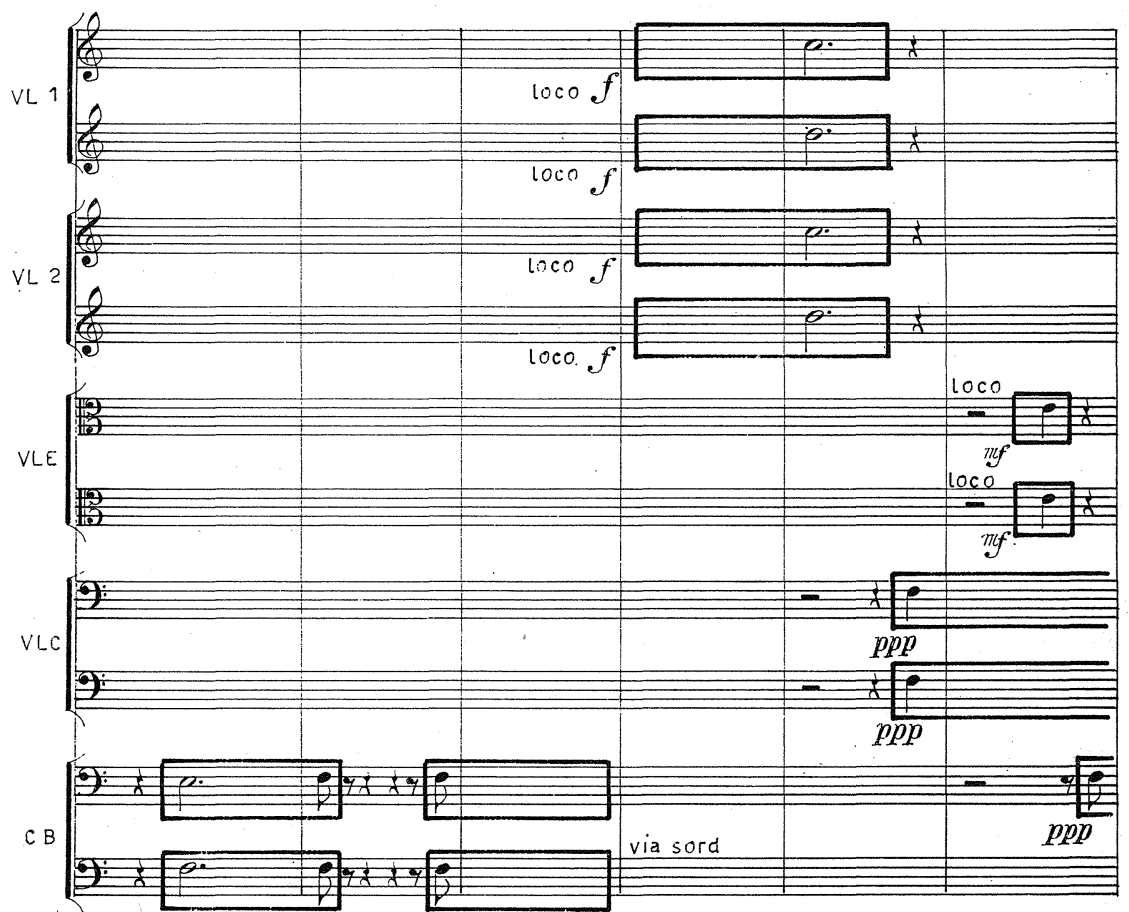

continuation of the $16^{\text {th }}$ century chori spezzatti technique and of even older antiphonal principles!

As mentioned before, from Enneaphonia onwards Ramovš "creates from the sound and for the sound's sake", or in other words: changes of density, colour and dynamics become the exclusive components of the work's "contents". ${ }^{23}$ In the Enneaphonia there is only one Italian literary adverb (espressivo) which, in spite of the disentimentalization of $20^{\text {th }}$ century music, because of tradition contains at least a certain degree of emotional qualities; henceforth, such expressions vanish from Ramovš's scores; only signs for way of producing sound, for dynamics as well as metronomic signs for tempo remain. Sound "becomes here an end in itself, self-sufficient, with no extra-tonal imputations", ${ }^{24}$ extra-musically explicitly

22 Echøes for flute and orchestra, DSS 532, HG/1048, Ljubljana 1973, $17,50,53,20$.

${ }^{23}$ Dibelius U., ib., 290.

${ }^{24}$ Rijavec A., Novejši slovenski godalni kvartet, Muzikološki zbornik IX/1973, 102. 
nonprogrammatic and thus more daring and more avantgarde. This being true of symphonic compositions is all the more characteristic of chamber works, each of which represents not only a continuation of former solutions but also a successful inclusion of new elements: the Colloquium for harp and string quartet (1970) is an actual continuation of the Triptychon for string quartet (1969), whereas a logical thread can be followed from the Oscillations through the Portrait for harp and chamber ensemble (1968) to the Thème donnè for trombone and ensemble (1972), which, for the first time, operates with deformed sounds.

Each time anew, Ramovšs delicate and rich inventiveness discovers new worlds of sound, in which a sensible and aesthetically acceptable arrangement of the formerly mentioned parametres is striven for. Form springs up from case to case or rather "grows organically", as he himself says. It is a fact that his points of departure are not "mathematical" i. e. explicitly intellectual, but they are fanatically, not to say romantically, devoted to sound. Not to label him with any hitherto indicated variant of emotional subjectivism, the statement just arrived at defines his compositional production of the last decade also stylistically. Ramovš does not actually want to express anything, at least anything supra-musical, but wants, similarly to his avantgarde contemporaries, to create with his music a new, constructed reality governed by complete autonomy. In this way he manages to remain as faithful as possible to himself, for abstract and seemingly wilful music is purest reality, concrete existence par excellence, music, which outside itself and beside itself has no message. However, a marginal remark is necessary: in these and such efforts of his Ramovš does not always appear to be consistent, for only the characteristic use of bells in the Symphony 68 or for example in the Symphony between the piano and orchestra betrays and localizes him geographically. And still an average listener is likely to say: "Das alles kann sehr interessant sein, es ist nur fraglich, ob es sich dabei noch um Musik handele; ob diese Art von 'Musik' noch überhaupt Kunst ist. Auf diese Frage könnte man wieder mit jener Frage antworten ...: Welchen Sinn schreiben wir der Kunst zu? Abermals sei betont, dass der Begriff des Wesens und des Sinnes der Kunst nicht konstant und unwandelbar ist und dass er deswegen im Zusammenhang mit allen Veränderungen, in denen wir zu existieren haben, dynamisch verstanden werden muss. Die Wandlungen des Menschen und der Welt $\mathrm{zu}$ verstehen, und der veränderte und manchmal unverständlich scheinende Sinn der Musik ist nicht nur aus ihr selbst zu erklären". ${ }^{25}$

25 Faltin P., Ontologische Transformationen in der Musik der Sechziger Jahren, Melos, März-April/1973, 70. 


\section{POVZETEK}

Kljub relativni uporabljivosti tradicionalnih stilnih pojmov, zlasti pri opredeljevanju novejše in najnovejše glasbe, kar se kaže tako $v$ domači kot $\mathrm{v}$ tuji leksikalni literaturi, predstavlja sestavek poizkus stilne opredelitve posameznih faz razvoja, ki in kakor ga odseva skladateljsko delo Primoža Ramovša. Predmet analize so bistvene značilnosti njegovega kompozicijskega stavka, tako $\mathrm{s}$ tehničnega kot zlasti $\mathrm{s}$ stilnega vidika, in sicer na podlagi upoštevanja najznačilnejših skladb, ki pomenijo obenem ključne točke skladateljeve stilne rasti: od prvih tehtnejših rezultatov, ki so še pod vplivom njegovih učiteljev, mimo najbolj dalekosežnega kompozicijskega preobrata $\mathrm{v}$ začetku šestdesetih let pa vse do dandanes se vleče logična razvojna kontinuiteta. Aplikacija standardnih stilnih epitetonov postaja sicer vse bolj vprašljiva čim bolj sega raziskava $\mathrm{v}$ neposredno sodobnost, vendar pa ob ustreznem prevrednotenju le-teh in ob upoštevanju ontoloških sprememb $\mathrm{v}$ glasbeni umetnosti šestdesetih let ne neuporabljiva. V tej luči se tudi s stilnega vidika kažejo paralele med Ramovševim opusom in sodobnimi evropskimi stilnimi gibanji. 